Check for updates

Cite this: RSC Adv., 2018, 8, 34151

\title{
Pyrolytic behavior of a zero-valent iron biochar composite and its $\mathrm{Cu}(\mathrm{II})$ removal mechanism
}

\author{
Changjiang $\mathrm{Yu}^{\mathrm{ab}}$ Dashuai Zhang, ${ }^{\mathrm{a}}$ Xinyu Dong ${ }^{\mathrm{a}}$ and Qiang Lin (D) *ab
}

The reduction behavior of $\mathrm{Fe}^{3+}$ during the preparation of a zero-valent iron cocoanut biochar (ZBC8-3) by the carbothermic reduction method was analyzed. $\mathrm{Fe}^{3+}$ was first converted into $\mathrm{Fe}_{3} \mathrm{O}_{4}$, which was subsequently decomposed into $\mathrm{FeO}$, and finally reduced to $\mathrm{Fe}^{0}$. A minor amount of $\gamma-\mathrm{Fe}_{2} \mathrm{O}_{3}$ was produced in the process. The isothermal thermodynamic data for the removal of $\mathrm{Cu}(\mathrm{I})$ over $\mathrm{ZBC} 8-3$ followed a Langmuir model. The Langmuir equation revealed a maximum removal capacity of $169.49 \mathrm{mg}$ $\mathrm{g}^{-1}$ at $\mathrm{pH}=5$ for ZBC8-3. The removal of $\mathrm{Cu}(\mathrm{II})$ over ZBC8-3 fitted well to a pseudo-first-order equation, which suggested that the rate limiting step of the process was diffusion. The $\mathrm{Cu}(I)$ removal mechanism on ZBC8-3 involved the reduction of $\mathrm{Cu}(\Perp)$ by $\mathrm{Fe}^{0}$ to produce $\mathrm{Cu}^{0}$ and $\mathrm{Cu}_{2} \mathrm{O}$, while $\mathrm{C}=\mathrm{C}$, $\mathrm{C}-\mathrm{O}-$, and $-\mathrm{O}-\mathrm{H}$ formed a complex with $\mathrm{Cu}(\mathrm{I})$.

Received 3rd July 2018 Accepted 23rd September 2018

DOI: 10.1039/c8ra05676e

rsc.li/rsc-advances
An alternative approach to produce nZVI for environmental remediation purposes is the carbothermic reduction method. In this method, an Fe-rich precursor is mixed with biomass and subsequently cofired under low-oxygen conditions. ${ }^{12}$ However, the reduction behavior of the Fe-rich precursor remains unclear. The main objective of this work is to determine the reduction behavior of the Fe-rich precursor during the preparation of a nZVI-biochar composite. Furthermore, the $\mathrm{Cu}(\mathrm{II})$ removal mechanism on the nZVI-biochar composite has not been reported yet. Therefore, our work was also aimed to investigate the mechanism for $\mathrm{Cu}(\mathrm{II})$ removal over the nZVIbiochar composite.

\section{Materials and methods}

\subsection{Materials}

Sodium alginate was purchased from Shanghai Jingchun Technology Co. Ltd. (Shanghai, China), while $\mathrm{FeCl}_{3} \cdot 6 \mathrm{H}_{2} \mathrm{O}$, $\mathrm{CaCl}_{2}$, and $\mathrm{NaOH}$ were purchased from Guangzhou chemical reagent factory (Guangzhou, China). $\mathrm{CuCl}_{2} \cdot 2 \mathrm{H}_{2} \mathrm{O}, \mathrm{PbCl}_{2}$, $\mathrm{CoCl}_{2} \cdot 6 \mathrm{H}_{2} \mathrm{O}$, and $\mathrm{NaNO}_{3}$ were purchased from Aladdin Holdings Group, and $\mathrm{Cu}$ standard liquid was obtained from Shanghai Fusheng Co. Ltd. (Shanghai, China). All analytical grade chemicals were used without further purification.

\subsection{Fabrication of magnetic carbon nanoadsorbents}

Cocoanut shell was collected from a suburb (Haikou, China), air-dried at $70{ }^{\circ} \mathrm{C}$ and ground (below $0.074 \mathrm{~mm}$ sieve). $60.0 \mathrm{~g}$ of $\mathrm{FeCl}_{3} \cdot 6 \mathrm{H}_{2} \mathrm{O}$ were dissolved in $500 \mathrm{~mL}$ of ethanol and the mixture was mechanically stirred for $1 \mathrm{~h} .10 .0 \mathrm{~g}$ of cocoanut shell powder was then mixed with the as-prepared $\mathrm{FeCl}_{3}$ solution and the suspension was stirred continuously for additional $24 \mathrm{~h}$ in order to homogenize $\mathrm{Fe}^{3+}$ in the cocoanut shell powders.

\footnotetext{
${ }^{a}$ Key Laboratory of Water Pollution Treatment \& Resource Reuse of Hainan Province, Key Laboratory of Tropical Medicinal Plant Chemistry of Ministry of Education, College of Chemistry and Chemical Engineering, Hainan Normal University, No. 99 Longkunnan Road, Haikou 571158, China. E-mail: linqianggroup@163.com

${ }^{b}$ Faculty of Environmental Science and Engineering, Kunming University of Science and Technology, No. 68 Wenchang Road, Kunming 650500, China
} 


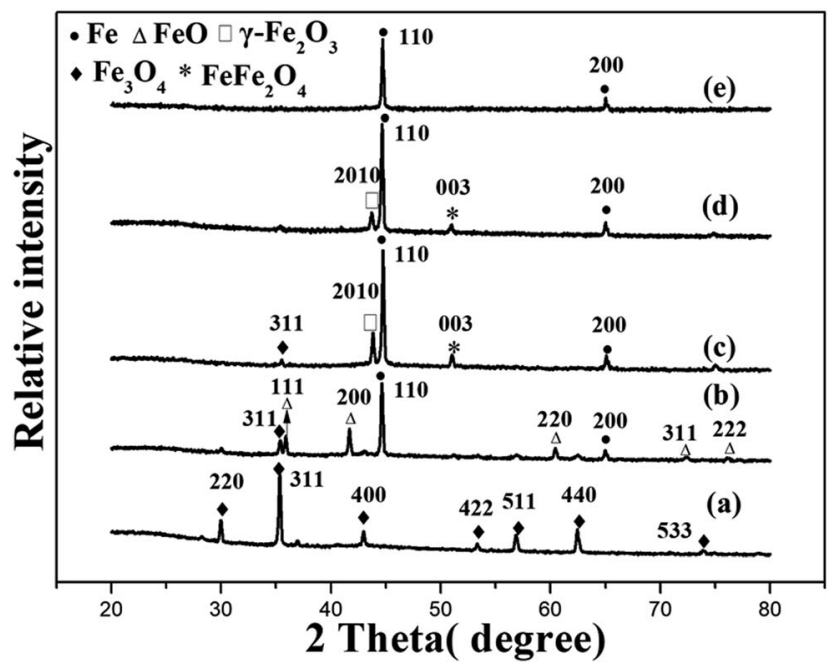

Fig. 1 XRD patterns of ZBC7-1 (a), ZBC7-3 (b), ZBC8-1 (c), ZBC8-2 (d) and ZBC8-3 (e).

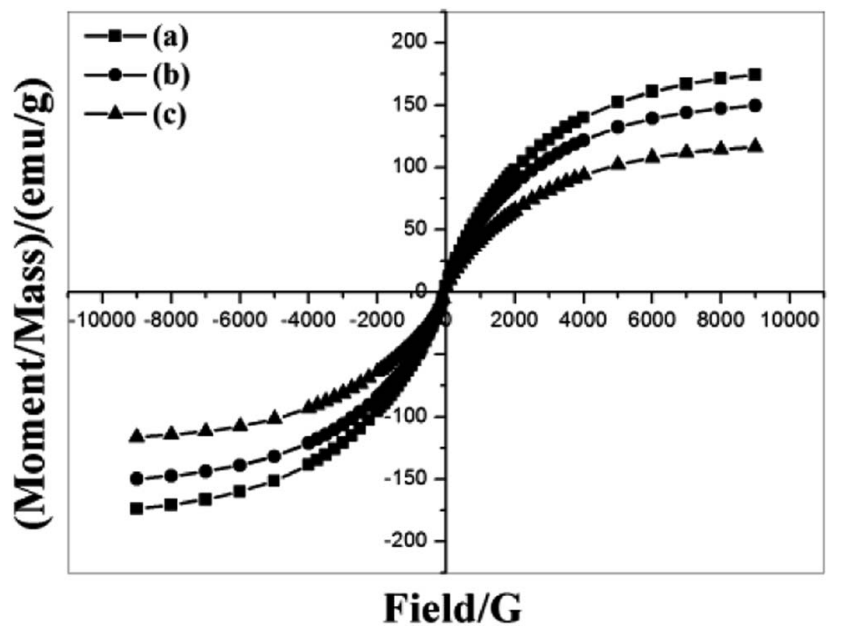

Fig. 2 The magnetization curves of ZBC8-3 (a), ZBC8-2 (b) and ZBC81 (c).

The mixture was kept at room temperature for one month. The remaining solids were dried in a convection oven at $120{ }^{\circ} \mathrm{C}$ for $10 \mathrm{~h}$ and pyrolyzed under nitrogen in a tube furnace to form magnetic carbon nanoadsorbents. The pyrolysis temperature was increased to $200{ }^{\circ} \mathrm{C}$ at $5{ }^{\circ} \mathrm{C} \mathrm{min}^{-1}$ and subsequently increased to 700 or $800{ }^{\circ} \mathrm{C}$ at $10{ }^{\circ} \mathrm{C} \mathrm{min}{ }^{-1}$ and held for $1-3 \mathrm{~h}$. The samples were named as ZBC a-b, where "a" and " $b$ " denote the carbonization temperature and the retention time, respectively.

\subsection{Characterization}

The $\mathrm{Cu}$ (II) concentration was determined by atomic absorption spectrophotometry (AAS, AA-7000, Shimadzu, Japan). The morphology of the samples was investigated by scanning electron microscopy (SEM, JSM-7401F, JEOL, Japan). Surface element analysis was conducted by energy dispersive spectroscopy (EDS). The structural and compositional characteristics of the materials were investigated by X-ray diffraction (XRD, UItima IV, Rigaku, Japan). X-ray photoelectron spectroscopy (XPS, PHI5000 Versaprobe-II, Ulvac-Phi, Japan) was used to analyze the chemical composition of the magnetic microspheres. The magnetic properties were determined using a magnetic property measurement system (7404, LakeShore, USA). The Fourier transform infrared (FTIR) spectra of the samples were obtained on a Nicolet 6700 infrared spectroscope (Thermo Electro Corp, USA).

\subsection{Adsorption kinetic studies}

The adsorption experiments on ZBC8-3 were carried out at $25{ }^{\circ} \mathrm{C}$. A Cu(II) stock solution of $100 \mathrm{mg} \mathrm{L}^{-1}$ was prepared by dissolving $\mathrm{CuCl}_{2} \cdot 2 \mathrm{H}_{2} \mathrm{O}$ in ultra-pure water. The solution was adjusted at $\mathrm{pH}=5$ using either $0.1 \mathrm{M} \mathrm{HNO}_{3}$ or $0.1 \mathrm{M} \mathrm{NaOH}$ solutions. A certain amount of ZBC8-3 was added to $500 \mathrm{~mL}$ of a $\mathrm{Cu}$ (II) solution in a beaker and shaken at a constant speed (120 $\mathrm{rpm}$ ) on a shaking table. $1 \mathrm{~mL}$ of the $\mathrm{Cu}(\mathrm{II})$ solution was removed at different times (from $10 \mathrm{~min}$ to $32 \mathrm{~h}$ ) and analyzed after dilution. ${ }^{\mathbf{1 3}}$ All the results were obtained by taking an average of three specimens. The adsorption capacity of $\mathrm{Cu}(\mathrm{II})$ at time $t\left(q_{t}\right)$ was then calculated using eqn (1):

$$
q_{t}=\frac{\left(C_{0}-C_{t}\right) V}{m}
$$

where $C_{0}\left(\mathrm{mg} \mathrm{L}^{-1}\right)$ is the initial $\mathrm{Cu}(\mathrm{II})$ concentration, $C_{t}\left(\mathrm{mg} \mathrm{L}^{-1}\right)$ is the $\mathrm{Cu}$ (II) concentration at time $t, V$ is the volume (L) of the $\mathrm{Cu}$ (II) solution, and $m$ is the weight (g) of ZBC8-3.

\subsection{Adsorption isotherms}

$0.05 \mathrm{~g}$ of ZBC8-3 were added to $\mathrm{Cu}(\mathrm{II})$ solutions $(200 \mathrm{~mL})$ with different concentrations $\left(50-250 \mathrm{mg} \mathrm{L}^{-1}\right)$ at $25{ }^{\circ} \mathrm{C}$ and shaken at a constant speed $(120 \mathrm{rpm})$ for $24 \mathrm{~h} .{ }^{14} \mathrm{Cu}$ (II) was quantified as in the case of the kinetic studies. All the results were obtained by taking an average of three specimens. The equilibrium adsorption capacity of $\mathrm{Cu}(\mathrm{II})\left(q_{\mathrm{e}}\right)$ was calculated using eqn (2):

$$
q_{\mathrm{e}}=\frac{\left(C_{0}-C_{\mathrm{e}}\right) V}{m}
$$

where $C_{0}\left(\mathrm{mg} \mathrm{L}^{-1}\right)$ and $C_{\mathrm{e}}$ are the initial and equilibrium concentrations of $\mathrm{Cu}(\mathrm{II})$, respectively, $V$ is the volume (L) of the $\mathrm{Cu}$ (II) solution, and $m$ is the weight (g) of ZBC8-3.

\subsection{Influence of other ions on the $\mathrm{Cu}$ (II) removal ability of ZBC8-3}

The hygienic standard for drinking water in China requires the $\mathrm{Cu}(\mathrm{II})$ concentration in drinking water to be less than $1 \mathrm{mg} \mathrm{L}^{-1}$, while nitrate concentration must be lower than $10 \mathrm{mg} \mathrm{L^{-1 }}$. In this study, a $\mathrm{Cu}(\mathrm{II})$ solution of $10 \mathrm{mg} \mathrm{L}^{-1}$ was selected as the simulated pollution source, while a $\mathrm{NaNO}_{3}$ solution of $10 \mathrm{mg} \mathrm{\textrm {L } ^ { - 1 }}$ was selected as a background electrolyte. To be specific, the $\mathrm{Cu}$ (II) solution of $10 \mathrm{mg} \mathrm{L}^{-1}$ fabricated by dissolving $\mathrm{CuCl}_{2}$ in ultrapure water was marked as sample 1 . Both $\mathrm{Cu}(\mathrm{II})$ 

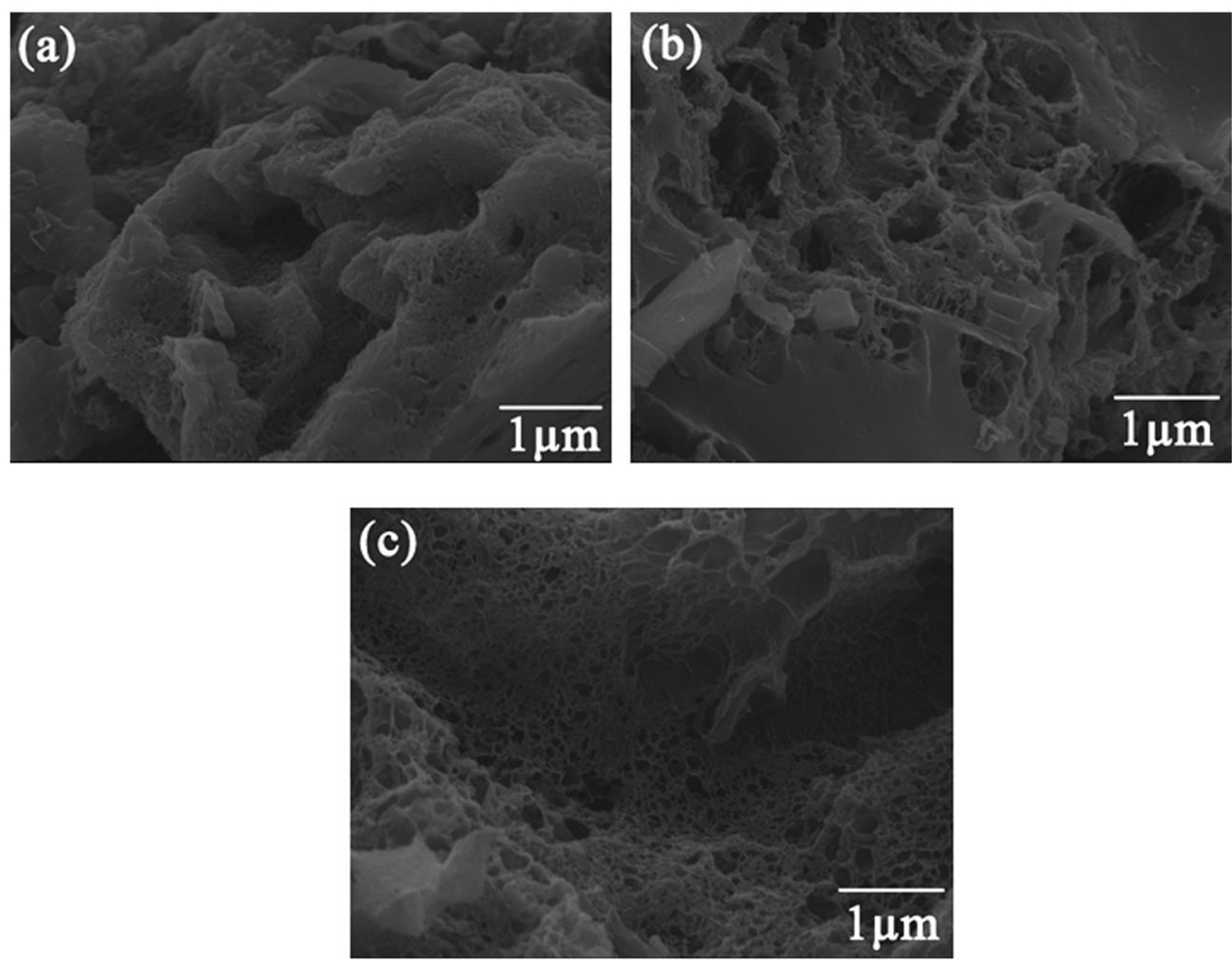

Fig. 3 SEM images of the surface of ZBC8-1 (a), ZBC8-2 (b) and ZBC8-3 (c).

and $\mathrm{NaNO}_{3} 10 \mathrm{mg} \mathrm{L}^{-1}$ solutions were marked as samples 2. In addition, $\mathrm{Pb}$ (II) $/ \mathrm{Cu}$ (II), $\quad \mathrm{Co}$ (II) $/ \mathrm{Cu}$ (II), and $\mathrm{Pb}$ (II) $/ \mathrm{Co}$ (II) $/ \mathrm{Cu}$ (II) mixtures were prepared by adding $\mathrm{PbCl}_{2}$ and $\mathrm{CoCl}_{2}$ to samples 2 , respectively, and were marked as samples 3, 4, and 5. Moreover, $0.1 \mathrm{~g}$ of ZBC8-3 were added respectively to samples 1-5 and shaken at a constant speed $(120 \mathrm{rpm})$ at $25{ }^{\circ} \mathrm{C}$ for $24 \mathrm{~h}$. After shaking, ZBC8-3 was filtered and the concentrations of $\mathrm{Cu}(\mathrm{II})$ in the filtered solutions were determined by AAS. All the results were obtained by taking an average of three specimens.

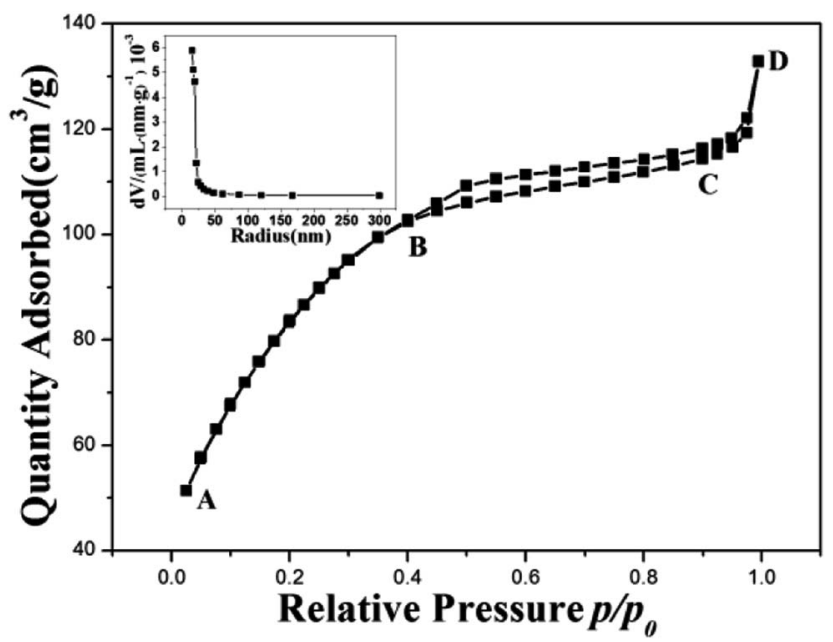

Fig. $4 \quad N_{2}$ adsorption-desorption isotherms and pore size distributions of $\mathrm{ZBC} 8-3$.

\section{Results and discussion}

\subsection{Characterization of materials}

3.1.1 Impact of the pyrolysis conditions on the iron ion reduction process. Fig. 1(a) shows the XRD pattern of ZBC7-1. The characteristic diffraction peaks were consistent with those of the normal card (JCPDS no. 65-3107) of $\mathrm{Fe}_{3} \mathrm{O}_{4} \cdot{ }^{15}$ Thus, the $2 \theta$ diffraction peaks at $30.1,35.5,43.1,53.5,57.0,62.6$, and $74.0^{\circ}$ corresponded to the crystal planes (220), (311), (400), (422), (511), (440), and (533) of $\mathrm{Fe}_{3} \mathrm{O}_{4}$, respectively. Fig. 1(b) shows the XRD pattern of ZBC7-3. The characteristic diffraction peaks revealed the presence of $\mathrm{Fe}^{0}$ (JCPDS no. 06-0696), ${ }^{16} \mathrm{FeO}$ (JCPDS no. 06-0615), ${ }^{17}$ and $\mathrm{Fe}_{3} \mathrm{O}_{4}$ (JCPDS no. 65-3107). ${ }^{15} 2 \theta$ diffraction peaks at 44.67 and $65.02^{\circ}$ corresponded to the crystal planes (110) and (200) of $\mathrm{Fe}^{0}$ respectively, while those at 36.04, 41.92, $60.76,72.73$, and $76.58^{\circ}$ corresponded to crystal planes (111), (200), (220), (311), and (222) of FeO respectively. The peak at $35.5^{\circ}$ corresponded to the crystal plane (311) of $\mathrm{Fe}_{3} \mathrm{O}_{4}$. Fig. 1(c) and (d) show the XRD patterns of ZBC8-1 and ZBC8-2, respectively. An increase in both the pyrolysis temperature and the retention time resulted in most $\mathrm{Fe}^{3+}$ being transformed to $\mathrm{Fe}^{0}$, and the onset of some diffraction peaks of $\gamma-\mathrm{Fe}_{2} \mathrm{O}_{3}$ (JCPDS no. 40-1139) ${ }^{18}$ and $\mathrm{FeFe}_{2} \mathrm{O}_{4}$ (JCPDS no. 28-0491). ${ }^{19}$ As shown in the XRD pattern of ZBC8-3 (Fig. 1(e)), most of $\mathrm{Fe}^{3+}$ was reduced to $\mathrm{Fe}^{0}$.

3.1.2 Magnetic properties. The hysteresis loops of $\mathrm{ZBC} 8-3$ (a), ZBC8-2 (b) and ZBC8-1 (c) are shown in Fig. 2. There were no remanence or coercivity, which indicated that the composites exhibited typical superparamagnetic behavior. ${ }^{20}$ The 


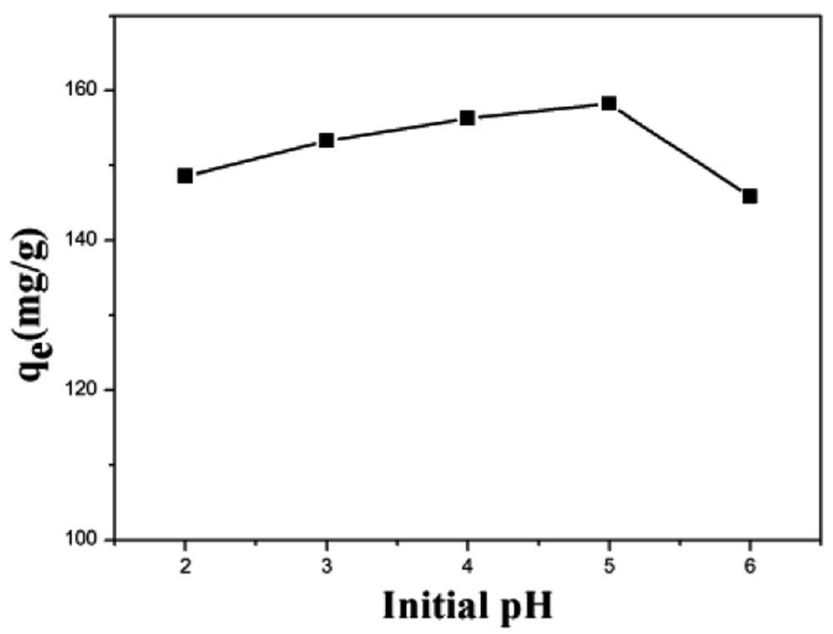

Fig. 5 Effect of the $\mathrm{pH}$ on the removal of $\mathrm{Cu}($ II) on ZBC8-3.

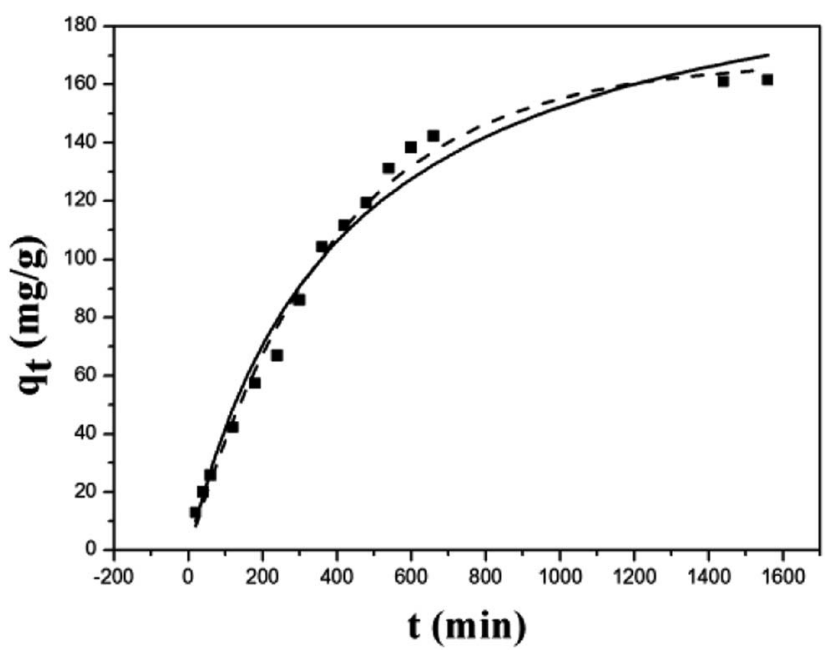

Fig. 6 Kinetic adsorption plots of the removal of $\mathrm{Cu}($ II) on ZBC8-3.

maximum saturation magnetizations of ZBC8-3, ZBC8-2, and ZBC8-1 were $170.04,149.77$, and $116.29 \mathrm{emu} \mathrm{g}^{-1}$, respectively. An increase in the retention time might have favored the formation of $\mathrm{Fe}^{0}$.

3.1.3 SEM analysis. The SEM images of the ZBC8-1 (a), ZBC8-2 (b), and ZBC8-3 (c) samples are shown in Fig. 3. As shown in these pictures, the nZVI-biochar composite underwent a rapid pore development at high retention time. Magnetic carbon nanoparticles were observed on the surface of the nZVIbiochar composite.

3.1.4 $\mathrm{N}_{2}$ adsorption-desorption isotherms and pore size distributions of ZBC8-3. The $\mathrm{N}_{2}$ adsorption-desorption isotherm and pore size distribution of ZBC8-3 are shown in Fig. 4. $\mathrm{N}_{2}$ adsorbed on ZBC8-3 first forming a monomolecular adsorption layer, which corresponded to the section $\mathrm{AB}^{21}$ Capillary condensation started in section BC, which was in the middle of the curve. At this stage, amount of gas adsorbed changed slowly with the relative pressure of $\mathrm{N}_{2}$, revealing a relatively wide $\mathrm{ZBC} 8-3$ pore diameter distribution. ${ }^{21}$ In the section $\mathrm{CD}$, the gas adsorption curve increased rapidly, and there was no sign of saturated adsorption even at pressures close to the saturated vapor pressure. This result revealed the presence of a certain amount of large pores in the sample with volumetric filling in large pores taking place by capillary condensation. ${ }^{22}$ The specific surface area of ZBC8-3 was 310.82 $\mathrm{m}^{2} \mathrm{~g}^{-1}$. According to the pore diameter distribution of ZBC8-3, most of the pores showed a radius within $15-25 \mathrm{~nm}$.

\subsection{Effect of the $\mathrm{pH}$ on the removal of $\mathrm{Cu}(\mathrm{II})$}

The $\mathrm{Cu}$ (II) removal experiments of ZBC7-1, ZBC7-3, ZBC8-1, ZBC8-2, and ZBC8-3 were carried out with a $\mathrm{Cu}$ (II) solution of $20 \mathrm{mg} \mathrm{L}^{-1}$ under constant shaking (120 rpm) for $24 \mathrm{~h}$ at $\mathrm{pH}=5$. The results showed that the removal capacity of ZBC7-1, ZBC7-3, ZBC8-1, ZBC8-2, and ZBC8-3 were 10.28, 29.15, 50.54, 61.86, and $73.50 \mathrm{mg} \mathrm{g}^{-1}$, respectively. An increase in the carbonization temperature and the retention time might have favored the formation of $\mathrm{Fe}^{0}$. Therefore, $\mathrm{ZBC} 8-3$ was selected as the raw material for subsequent experiments. The effect of the $\mathrm{pH}$ on the removal capacity of ZBC8-3 was investigated. Adsorption experiments were carried with a $\mathrm{Cu}(\mathrm{II})$ solution of $90 \mathrm{mg} \mathrm{\textrm {L } ^ { - 1 }}$ over a $\mathrm{pH}$ range of 2-6, since $\mathrm{Cu}$ (II) precipitate above a $\mathrm{pH}$ of $6 .{ }^{23}$ All the results were obtained by taking an average of three specimens.

The removal capacity of ZBC8-3 increased quickly with the $\mathrm{pH}$ (Fig. 5). This can be explained as follows. At lower $\mathrm{pH}$, a higher number of very mobile protons $\left(\mathrm{H}^{+}\right)$compete with $\mathrm{Cu}(\mathrm{II})$ ions for the active sites on ZBC8-3. Upon increasing the $\mathrm{pH}$, the concentration of $\mathrm{H}^{+}$ions decreased, resulting in more $\mathrm{Cu}(\mathrm{II})$ being replaced. ${ }^{24}$ In addition, the $\mathrm{Cu}(\mathrm{II})$ removal capacity of ZBC8-3 decreased significantly at a $\mathrm{pH}$ of $=6$, which may result from $\mathrm{Fe}^{3+} / \mathrm{Fe}^{2+}$ depositions easily generated at high $\mathrm{pH}$ covering the surface of ZBC8-3. These deposits prevented the diffusion of $\mathrm{Cu}$ (II) into ZBC8-3. Therefore, $\mathrm{pH}=5$ was chosen as the optimum experimental conditions. ${ }^{25}$

\subsection{Kinetics adsorption experiments}

The kinetics of the $\mathrm{Cu}$ (II) removal on ZBC8-3 were investigated by using dynamic data. Pseudo-first-order and pseudo-secondorder kinetic models were applied to fit the data, as described in eqn (3) and (4). ${ }^{26}$ The result for non-linear curve fitting to the dynamic data is shown in Fig. 6:

Table 1 Kinetics parameter coefficients for CU(॥) removal on ZBC8-3

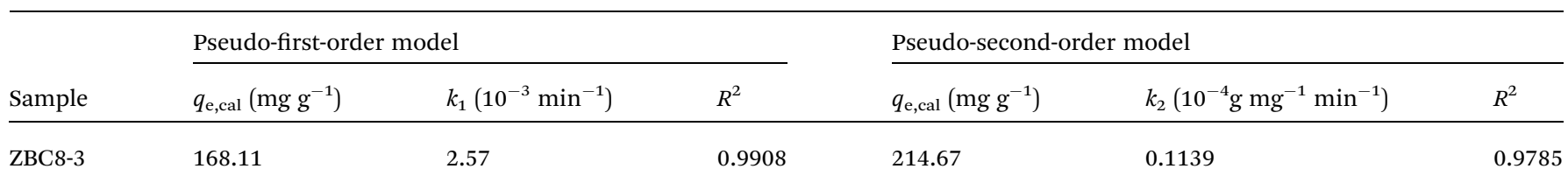



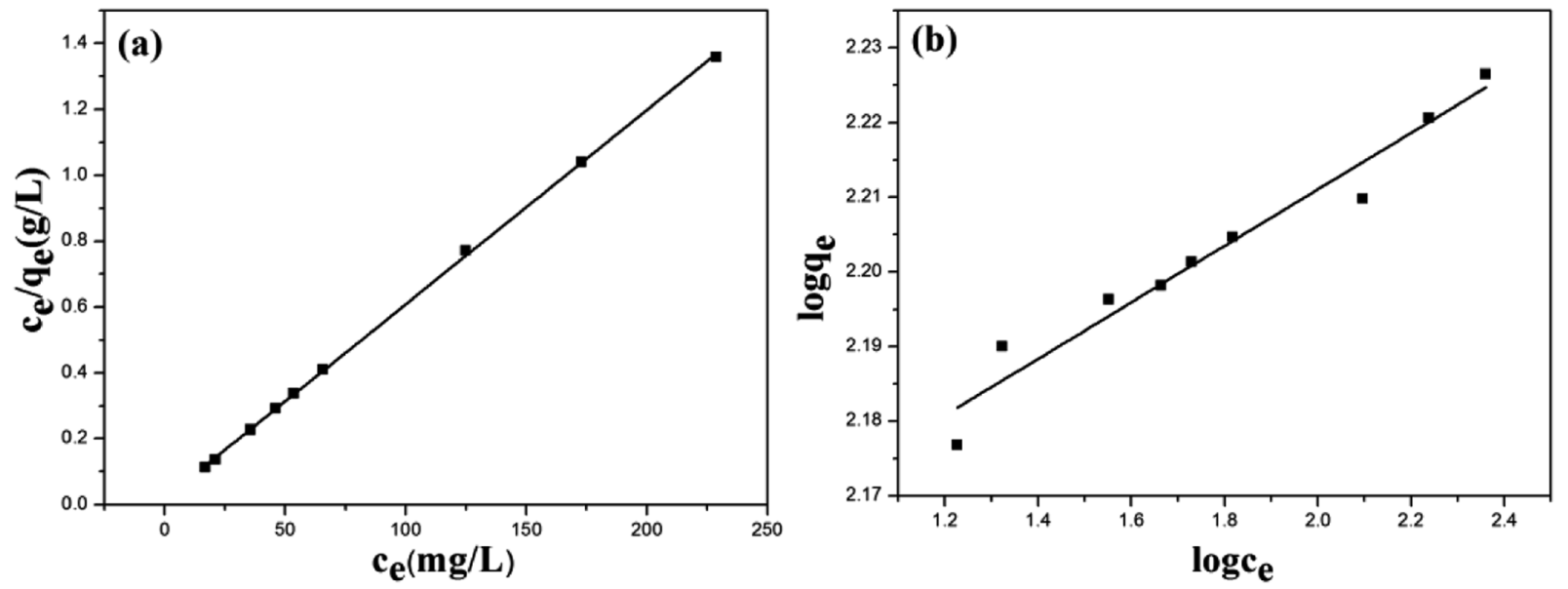

Fig. 7 Adsorption isotherms of Langmuir (a) and Freundlich (b) equations for the removal of Cu(II) on ZBC8-3.

Table 2 Isotherm parameters for the removal of $\mathrm{Cu}($ II) on ZBC8-3

\begin{tabular}{|c|c|c|c|c|c|c|}
\hline \multirow[b]{2}{*}{ Sample } & \multicolumn{3}{|l|}{ Langmuir } & \multicolumn{3}{|c|}{ Freundlich } \\
\hline & $q_{\mathrm{m}}\left(\mathrm{mg} \mathrm{g}^{-1}\right)$ & $K_{\mathrm{L}}\left(\mathrm{L} \mathrm{mg}^{-1}\right)$ & $R^{2}$ & $1 / n$ & $K_{\mathrm{F}}\left(\mathrm{mg} \mathrm{g}^{-1}\right)$ & $R^{2}$ \\
\hline ZBC8-3 & 169.49 & 0.3181 & 0.9997 & 0.0378 & 136.58 & 0.9510 \\
\hline
\end{tabular}

$$
\begin{aligned}
\log \left(q_{\mathrm{e}}-q_{t}\right) & =\log q_{\mathrm{e}}-\left(\frac{k_{1}}{2.303}\right) t \\
\frac{t}{q_{\mathrm{e}}} & =\frac{1}{k_{2} q_{\mathrm{e}}^{2}}+\frac{t}{q_{\mathrm{e}}}
\end{aligned}
$$

where $q_{t}$ and $q_{\mathrm{e}}$ are the amounts of $\mathrm{Cu}(\mathrm{II})$ removed per unit mass of ZBC8-3 in $\mathrm{mg} \mathrm{g}^{-1}$ at an arbitrary contact time $t(\mathrm{~s})$ and at equilibrium stage. $k_{1}$ and $k_{2}$ are the pseudo-first-order and pseudo-second-order kinetic constants expressed in $\min ^{-1}$ and $\mathrm{g} \mathrm{mg}^{-1} \mathrm{~min}^{-1}$, respectively.

As shown in Fig. 6, the removal of $\mathrm{Cu}$ (II) on $\mathrm{ZBC} 8-3$ was fast within the first $6 \mathrm{~h}$, and the rate decreased thereafter and stabilized within $24 \mathrm{~h}$. The relatively fast removal rate within the first $6 \mathrm{~h}$ was mainly attributed to an oxidation-reduction reaction of $\mathrm{Fe}^{0}$ on the outer layer of ZBC8-3. Some deposits were formed by redox reaction of $\mathrm{Fe}^{0}$ and $\mathrm{Cu}(\mathrm{II})$, blocking the pore structure of the ZBC8-3 to some extent. As a result, diffusion of $\mathrm{Cu}(\mathrm{II})$ to the inside of the ZBC8-3 was hindered in the consequent reaction.

The kinetic model parameters as well as the correlation coefficient $\left(R^{2}\right)$ for ZBC8-3 are included in Table 1.

The pseudo-first-order equation described the $\mathrm{Cu}$ (II) removal behavior on ZBC8-3. The correlation coefficient (0.9908) for ZBC8-3 was higher than that of the pseudo-second-order equation (0.9785), indicating that the rate limiting step was diffusion. ${ }^{27}$ Thus, the surface of ZBC8-3 was covered by deposits, which blocked the porous structure of $\mathrm{ZBC} 8-3$. $\mathrm{Cu}$ (II) ions gradually diffused to the interior of $\mathrm{ZBC} 8-3$, and the overall process required more time to complete.

\subsection{Isothermal adsorption experiments}

The removal isotherms were fitted using the Langmuir and Freundlich isotherm models. The Langmuir isotherm model is described by eqn (5): ${ }^{28}$

$$
\frac{c_{\mathrm{e}}}{q_{\mathrm{e}}}=\frac{1}{K_{\mathrm{L}} q_{\mathrm{m}}}+\frac{c_{\mathrm{e}}}{q_{\mathrm{m}}}
$$

where, $c_{\mathrm{e}}\left(\mathrm{mg} \mathrm{L}^{-1}\right)$ is the concentration of $\mathrm{Cu}(\mathrm{II})$ ions at equilibrium, $q_{\mathrm{m}}\left(\mathrm{mg} \mathrm{g}^{-1}\right)$ is the Langmuir adsorption maximum, $K_{\mathrm{L}}$

\begin{tabular}{|c|c|c|c|c|}
\hline Adsorbents & $\mathrm{pH}$ & $\begin{array}{l}\text { Concentration } \\
\text { range }\left(\mathrm{mg} \mathrm{L}^{-1}\right)\end{array}$ & $Q_{\max }\left(\mathrm{mg} \mathrm{g}^{-1}\right)$ & Ref. \\
\hline Functionalized magnetic nanoparticles & 5 & $10-100$ & 34.08 & 31 \\
\hline $\mathrm{Mg}-\mathrm{Al}-\mathrm{D}_{2} \mathrm{EHPA}$ & 5 & 100 & 68.66 & 32 \\
\hline M-HAP/agar composite beads & 5 & $10-200$ & 71.6 & 33 \\
\hline Carbon aerogels & - & $0-400$ & 86.27 & 22 \\
\hline Sugarcane bagasse trimellitate & 5.5 & 60 & 67.84 & 34 \\
\hline Bifunctional ordered mesoporous silica & 5 & $10-50$ & 90.61 & 35 \\
\hline Ph-PAni nanofibers & 5.3 & $6.4-64$ & 5.29 & 36 \\
\hline Magnetic nanoscale zerovalent iron assisted biochar & 6 & - & 30.37 & 37 \\
\hline Chitosan enwrapping $\mathrm{Fe}_{3} \mathrm{O}_{4}$ and graphene oxide & 6 & 500 & 132 & 38 \\
\hline ZBC8-3 & 5 & $50-250$ & 169.49 & This study \\
\hline
\end{tabular}
is the coefficient of distribution for the removal of $\mathrm{Cu}(\mathrm{II})$, and $q_{\mathrm{e}}$

Table 3 Comparison of the adsorption potential of various adsorbents for copper ion removal from water 


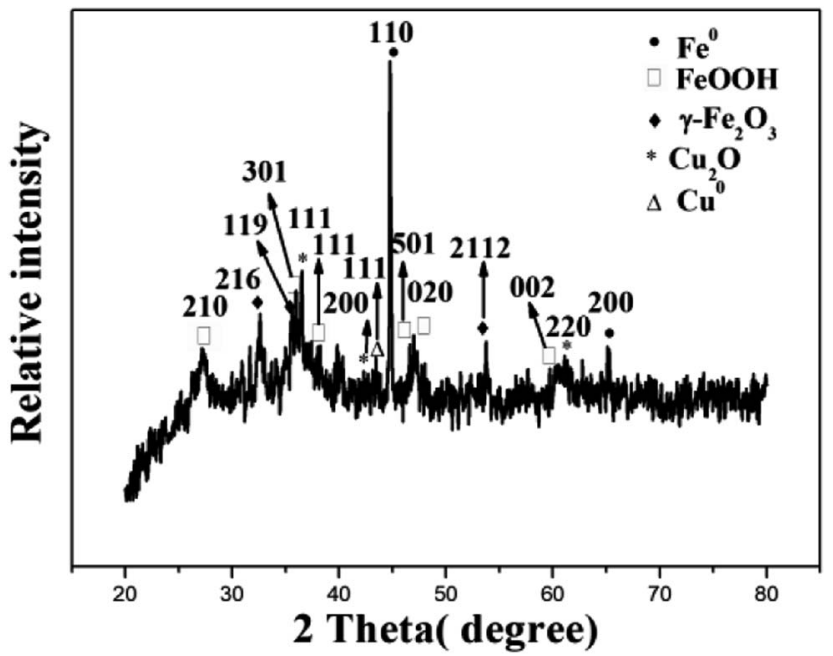

Fig. 8 XRD pattern of ZBC8-3 after Cu(II) removal.
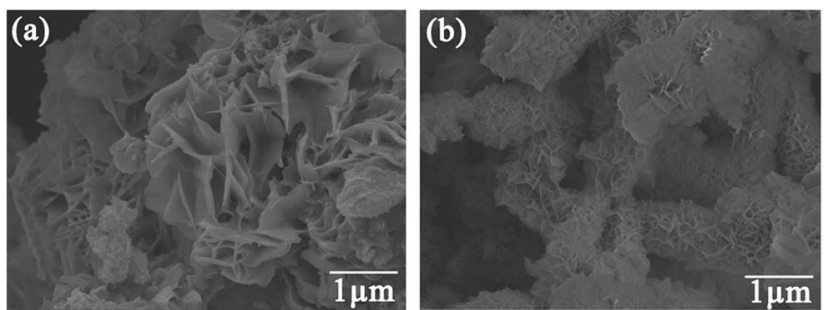

Fig. 9 SEM images of the surface of ZBC8-3 after $\mathrm{Cu}($ (I) removal.

is the amount of $\mathrm{Cu}(\mathrm{II})$ ions removed per unit mass of ZBC8-3 in $\mathrm{mg} \mathrm{g}^{-1}$ at equilibrium stage.

The Freundlich isotherm model is described by eqn (6): ${ }^{29}$

$$
\log q_{\mathrm{e}}=\log K_{\mathrm{F}}+\frac{1}{n} \log C_{\mathrm{e}}
$$

$K_{\mathrm{F}}$ is the coefficient of distribution for the adsorption process.

The Langmuir and Freundlich isotherms of ZBC8-3 are shown in Fig. 7. The results showed that the $\mathrm{Cu}(\mathrm{II})$ ion removal

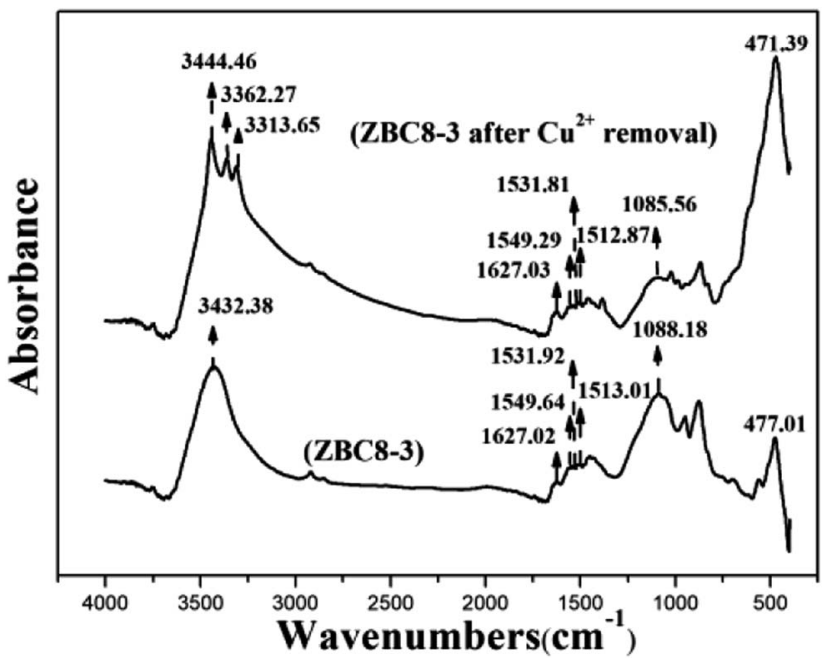

Fig. 11 FTIR pattern of ZBC8-3 before and after being treated with Cu(II).

capacity increased rapidly at low concentrations of $\mathrm{Cu}$ (II) and gradually reached its maximum by increasing the $\mathrm{Cu}(\mathrm{II})$ ion concentration.

The isotherms model parameter and the correlation coefficient $\left(R^{2}\right)$ for ZBC8-3 are summarized in Table 2.

As shown in Table 2, the correlation coefficient of the Langmuir model adsorption isotherm plots was high (0.9997) for the ZBC8-3. The high $R^{2}$ suggested that the Langmuir model fitted the adsorption data well. The homogeneous nature of the active sites on the adsorbents might have favored a monolayer removal behavior of $\mathrm{Cu}(\mathrm{II})$ ions on $\mathrm{ZBC} 8-3 .^{30}$

\subsection{Comparison with other adsorbents}

The removal capacity $\left(q_{\mathrm{m}}\right)$ for $\mathrm{Cu}(\mathrm{II})$ on ZBC8-3 obtained herein was comparable with those reported in the literature for other adsorbents (Table 3). ZBC8-3 showed promising results for the removal of $\mathrm{Cu}$ (II) from aqueous solutions (i.e., a relatively high removal capacity).
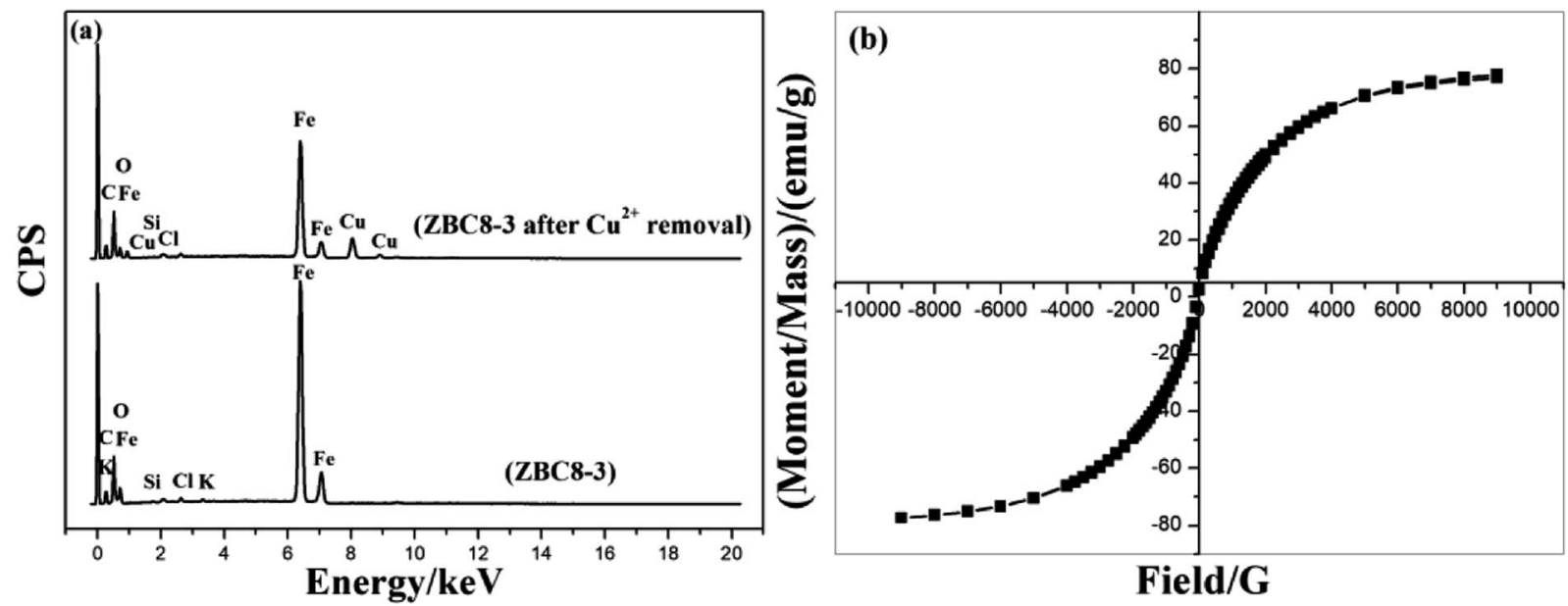

Fig. 10 EDS pattern of ZBC8-3 before and after $\mathrm{Cu}(॥)$ removal (a) and the magnetization curve of ZBC8-3 after Cu(॥) removal (b). 

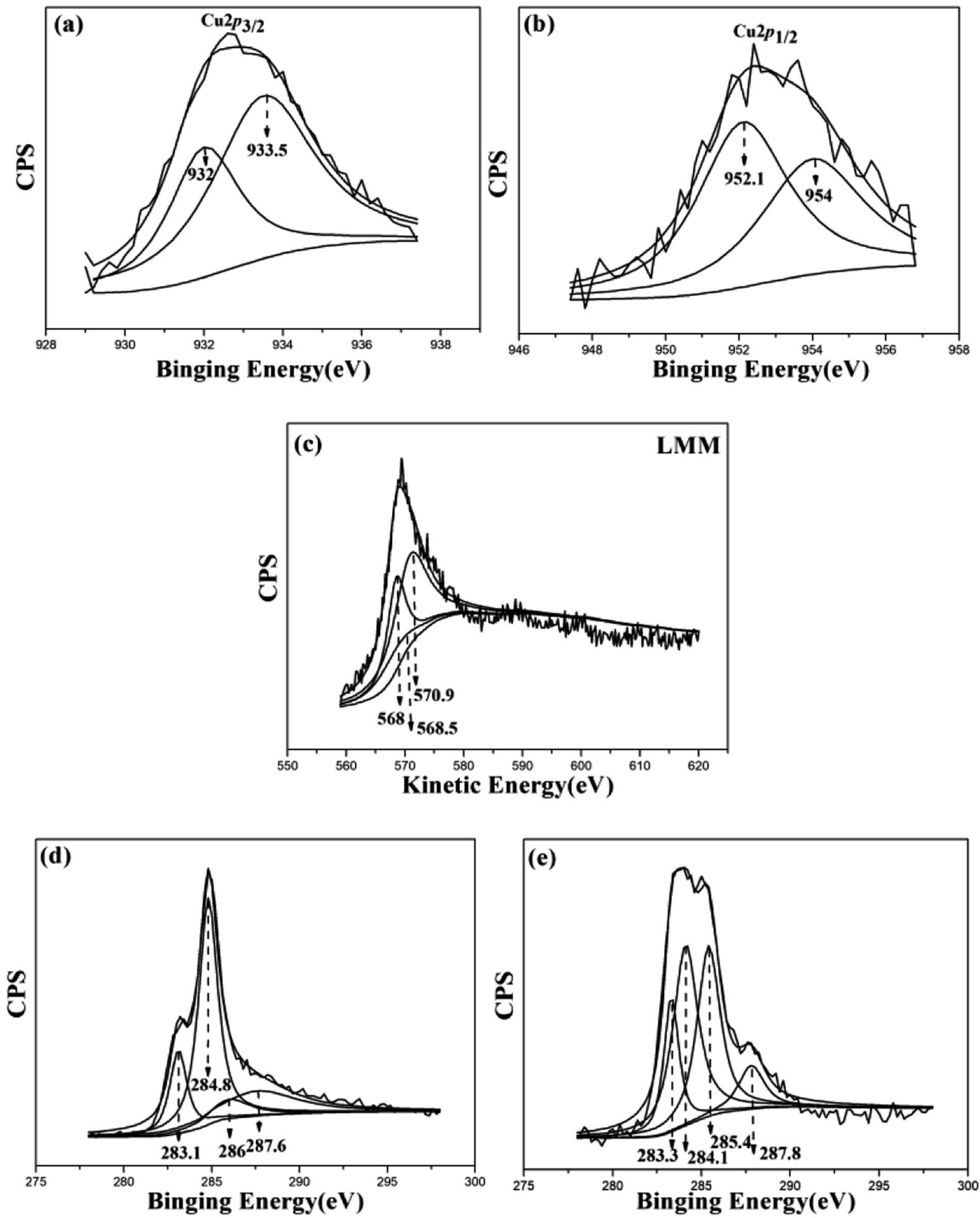

Fig. $12 \mathrm{Cu}_{2} \mathrm{p}_{3 / 2}$ for ZBC8-3 after Cu(॥) removal (a), Cu 2 $\mathrm{p}_{1 / 2}$ for ZBC8-3 after Cu(॥) removal (b), Cu LMM for ZBC8-3 after Cu(॥) removal (c), C 1s for ZBC8-3 before (d) and after (e) Cu(॥) removal.

\subsection{Adsorption mechanism}

Fig. 8 shows the XRD pattern of ZBC8-3 after reaction with $\mathrm{Cu}(\mathrm{II})$. The characteristic diffraction peaks revealed the presence of $\mathrm{Cu}_{2} \mathrm{O}$ (JCPDS no. 05-0667), ${ }^{39} \gamma-\mathrm{Fe}_{2} \mathrm{O}_{3}$ (JCPDS no. 25-1402) ${ }^{40}$, FeOOH (JCPDS no. 44-1415), ${ }^{41} \mathrm{Fe}^{0}$ (JCPDS no. 06-0696) ${ }^{41}$ and
$\mathrm{Cu}^{0}$ (JCPDS no. 04-0836). ${ }^{42}$ The $2 \theta$ diffraction peaks at 36.42 , 42.30 , and $61.34^{\circ}$ corresponded to the crystal planes (111), (200), and (220) of $\mathrm{Cu}_{2} \mathrm{O}$, respectively. The peaks at 32.17, 35.68, and $50.08^{\circ}$ corresponded to the crystal planes (216), (119), and (2112) of $\gamma-\mathrm{Fe}_{2} \mathrm{O}_{3}$, respectively. The peaks at 27.04, 36.29, 38.07, 
46.78, 46.91, and $60.26^{\circ}$ were ascribed to the crystal planes (210), (301), (111), (501), (020), and (002) of FeOOH. In addition, the XRD pattern indicated the presence of $\mathrm{Fe}^{0}(2 \theta=44.67$ and $\left.65.02^{\circ}\right)$ and $\mathrm{Cu}^{0}\left(2 \theta=43.30^{\circ}\right)$. Therefore, from the results of Fig. 8, most of $\mathrm{Cu}$ (II) was reduced to $\mathrm{Cu}^{0}$ and $\mathrm{Cu}_{2} \mathrm{O}$, while most of nZVI was converted to $\mathrm{FeOOH}$ and $\gamma-\mathrm{Fe}_{2} \mathrm{O}_{3}$. In addition, a fraction of nZVI did not react with $\mathrm{Cu}(\mathrm{II})$.

Fig. 9 shows the SEM patterns of ZBC8-3 after reaction with $\mathrm{Cu}(\mathrm{II})$. ZBC8-3 was covered by the reaction products (e.g., $\mathrm{Cu}_{2} \mathrm{O}$, $\mathrm{Cu}^{0}, \mathrm{FeOOH}$, and $\left.\gamma-\mathrm{Fe}_{2} \mathrm{O}_{3}\right)$ on its surface. The original porous structure of ZBC8-3 was therefore blocked.

Fig. 10(a) shows the EDS patterns of ZBC8-3 before and after reaction with $\mathrm{Cu}$ (II). The results revealed that the amount of $\mathrm{Fe}$ on ZBC8-3 decreased after reaction with $\mathrm{Cu}$ (II) from 82.87 to $56.74 \mathrm{wt} \%$. The amount of $\mathrm{Cu}$ on the surface of ZBC8-3 after reaction with $\mathrm{Cu}$ (II) was $19.95 \mathrm{wt} \%$. As shown in Fig. 10(b), the maximum saturation magnetization of ZBC8-3 after reaction with $\mathrm{Cu}$ (II) was $77.6 \mathrm{emu}^{-1}$. Thus, the solid can be separated readily by using a magnet.

FTIR was used to study the molecular interactions and analyze the functional groups of $\mathrm{ZBC} 8-3$ before and after the $\mathrm{Cu}$ (II) removal process. As shown in Fig. 11, ZBC8-3 revealed a stretching vibration peak of $\mathrm{O}-\mathrm{H}$ at $3432.58 \mathrm{~cm}^{-1}$, $^{30}$ a stretching vibration peak of $\mathrm{C}=\mathrm{O}$ at $1627.02 \mathrm{~cm}^{-1},{ }^{43}$ stretching vibration peak of aromatic ring at 1549.64, 1531.92, and $1513.01 \mathrm{~cm}^{-1},{ }^{44}$ stretching vibration peaks of $\mathrm{C}-\mathrm{O}-\mathrm{C}$ and $\mathrm{Si}-\mathrm{O}$ at $1088.18 \mathrm{~cm}^{-1},{ }^{45}$ and a bending vibration peak of $\mathrm{Fe}-\mathrm{O}$ at $477.01 \mathrm{~cm}^{-1} .{ }^{46}$ The adsorption peak was characteristic of the $\mathrm{Fe}-\mathrm{O}$ bond, possibly because part of $\mathrm{Fe}^{0}$ was oxidized during the grinding process. The FTIR spectra of ZBC8-3 after $\mathrm{Cu}$ (II) removal revealed that some adsorption peaks were slightly shifted. The stretching vibration peaks of the aromatic ring, C$\mathrm{O}-\mathrm{C}$, and $\mathrm{Si}-\mathrm{O}$ shifted to lower wavenumber, which might result from those functional groups being complexed with $\mathrm{Cu}$ (II). The increased ionic volume weakened the stretching and bending vibrations of the functional groups and caused the downfield shift. ${ }^{47}$ The $\mathrm{O}-\mathrm{H}$ peak after $\mathrm{Cu}(\mathrm{II})$ removal was observed at longer wavenumbers than before the removal process. This shifting to higher wavenumbers may be attributed to an inductive effect. ${ }^{48}$ The wavelength of the $\mathrm{C}=\mathrm{O}$ peak hardly changed after $\mathrm{Cu}(\mathrm{II})$ removal. In addition, several new peaks ascribed to $\mathrm{FeOOH}$ appeared for $\mathrm{ZBC} 8-3$ after $\mathrm{Cu}(\mathrm{II})$ removal. (i.e., a bending vibration peak of $\mathrm{Fe}-\mathrm{O}$ at $417.39 \mathrm{~cm}^{-146}$ and stretching vibration peaks of $\mathrm{O}-\mathrm{H}$ at 3362.27 and $\left.3313.65 \mathrm{~cm}^{-1}\right)^{49}$.

The XPS analysis of $\mathrm{Cu}$ in $\mathrm{ZBC} 8-3$ after reaction with $\mathrm{Cu}(\mathrm{II})$ is shown in Fig. 12(a) and (b). Each adsorption peak of $\mathrm{Cu} 2 \mathrm{p}_{3 / 2}$ and $\mathrm{Cu} 2 \mathrm{p}_{1 / 2}$ were deconvoluted into 2 peaks. The peaks at 932 and $952.1 \mathrm{eV}$ could be ascribed to $\mathrm{Cu}_{2} \mathrm{O}$ and $\mathrm{Cu}^{0}$ species, respectively, while, the adsorption peaks at 933.5 and $954 \mathrm{eV}$ could be ascribed to $\mathrm{Cu}(\mathrm{II})$ species. Auger electron spectroscopy was used to study $\mathrm{Cu}$ more in detail (Fig. 12(c)). With reference to the standard data, the adsorption peaks at 568, 568.5, and $570.9 \mathrm{eV}$ could be ascribed to $\mathrm{Cu}^{0}, \mathrm{Cu}(\mathrm{II})$, and $\mathrm{Cu}_{2} \mathrm{O}$ species, respectively. The XPS analysis for $\mathrm{C}$ in $\mathrm{ZBC} 8-3$ is shown in Fig. 12(d). The adsorption peak at $283.1 \mathrm{eV}$ could be ascribed to $\mathrm{Si}-\mathrm{C}$ bond, ${ }^{50}$ the adsorption peak at $284.8 \mathrm{eV}$ could be ascribed to $\mathrm{C}-\mathrm{C}$ or $\mathrm{C}=\mathrm{C}$ bonds, ${ }^{44,51}$ the adsorption peak at $286 \mathrm{eV}$ can be

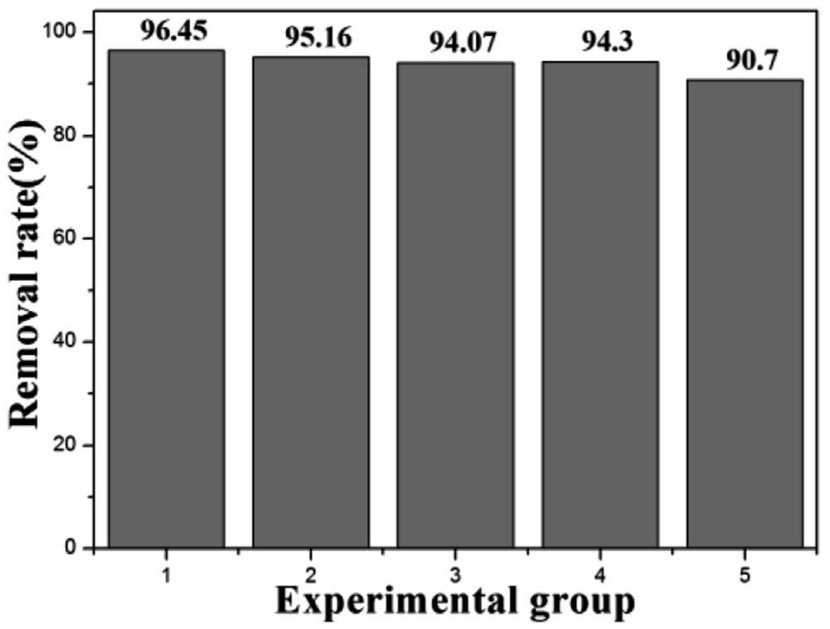

Fig. 13 The effect of other ions on ZBC8-3 removal of Cu(II).

produced by $\mathrm{C}-\mathrm{O}$ bond, and the peak at $287.6 \mathrm{eV}$ could be attributed to $\mathrm{C}=\mathrm{O}$ bonds. ${ }^{\mathbf{4 4 , 5 1}}$ The XPS analysis for $\mathrm{C}$ in ZBC8-3 after reaction with $\mathrm{Cu}(\mathrm{II})$ is shown in Fig. 12(e). The binding energy of $\mathrm{Si}-\mathrm{C}$ and $\mathrm{C}=\mathrm{O}$ changed slightly before and after $\mathrm{Cu}$ (II) removal, which indicated that $\mathrm{Si}-\mathrm{C}$ and $\mathrm{C}=\mathrm{O}$ may not involve the removal of $\mathrm{Cu}(\mathrm{II})$. The binding energy of $\mathrm{C}=\mathrm{C}$ and $\mathrm{C}-\mathrm{O}$ decreased significantly compared to those before the removal of $\mathrm{Cu}$ (II), which indicated that $\mathrm{C}=\mathrm{C}, \mathrm{C}-\mathrm{O}$, and $\mathrm{Cu}$ (II) species could have formed a coordination compound. Thus, the binding energy of the functional groups was reduced owing to changes in the electronic densities of the groups in relation with their local environment. ${ }^{52}$

\subsection{The effect of other ions on the removal of $\mathrm{Cu}$ (II) on $\mathrm{ZBC} 8-3$}

Fig. 13 shows the effect of other ions on the removal of $\mathrm{Cu}$ (II) over ZBC8-3. The $\mathrm{Cu}(\mathrm{II})$ removal rate of sample 2 was slightly lower than that of sample 1. Thus, nitrate showed a certain influence on the removal of $\mathrm{Cu}$ (II). The $\mathrm{Cu}$ (II) removal rates of samples 3 and 4 were lower than that of sample 2. $\mathrm{Pb}$ (II) and $\mathrm{Co}$ (II) ions showed a comparatively large influence on the removal of $\mathrm{Cu}$ (II). The $\mathrm{Cu}$ (II) removal rate of sample 5 decreased significantly, while the $\mathrm{Cu}(\mathrm{II})$ concentrations of samples 1, 2, 3, 4 and 5 were $0.35,0.48,0.59,0.57$ and $0.93 \mathrm{mg} \mathrm{L}^{-1}$ after $\mathrm{Cu}(\mathrm{II})$ removal, respectively. Since the standard electrode potential of $\mathrm{E}^{\ominus} \mathrm{Cu}^{2+} / \mathrm{Cu}(0.342 \mathrm{~V})$ is higher than that of $\mathrm{E}^{\ominus} \mathrm{Pb}^{2+} / \mathrm{Pb}(-0.126 \mathrm{~V})$ and $\mathrm{E}^{\ominus} \mathrm{Co}^{2+} / \mathrm{Co}(-0.28 \mathrm{~V}), \mathrm{Cu}(\mathrm{II})$ ions are more easily reduced. Since the hygienic standard for drinking water in china requires that $\mathrm{Cu}$ (II) concentrations in drinking below $1 \mathrm{mg} \mathrm{L}^{-1}$, ZBC8-3 can be used to remove $\mathrm{Cu}(\mathrm{II})$ ions from wastewater.

\section{Conclusions}

A nZVI biochar composite derived from cocoanut shell was fabricated by a calcination method by using $\mathrm{FeCl}_{3}$ as the iron precursor. The maximum saturation magnetization of ZBC8-3 before and after $\mathrm{Cu}$ (II) removal were 170.04 and $77.6 \mathrm{emu}^{-1}$, respectively, allowing easy separation of the solid after $\mathrm{Cu}$ (II) removal by using a magnet. The $\mathrm{Cu}(\mathrm{II})$ removal capacity of ZBC8- 
3 was as high as $169.49 \mathrm{mg} \mathrm{g}^{-1}$ because of its higher content of nZVI. Thus, this material can be used to remove $\mathrm{Cu}(\mathrm{II})$ ions from wastewater.

\section{Conflicts of interest}

There are no conflicts.

\section{Acknowledgements}

This work was supported by the Key Research and Development Project of Hainan Province of China (Project No. ZDYF2017102), Natural Science Foundation of Hainan Province of China (Project No. 20162032).

\section{References}

1 L. Qian, W. Zhang, J. Yan, L. Han, Y. Chen, D. Ouyang and M. Chen, Environ. Pollut., 2017, 223, 153-160.

2 X. Jiang, Z. Ouyang, Z. Zhang, C. Yang, X. Li, Z. Dang and P. Wu, Colloids Surf., A, 2018, 547, 64-72.

3 Z. Li, L. Wang, J. Meng, X. Liu, J. Xu, F. Wang and P. Brookes, J. Hazard. Mater., 2018, 344, 1-11.

4 L. Dong, L. Lin, Q. Li, Z. Huang, X. Tang, M. Wu, C. Li, X. Cao and M. Scholz, J. Environ. Manage., 2018, 213, 151-158.

5 C. Xu, W. Yang, W. Liu, H. Sun, C. Jiao and A.-j. Lin, J. Environ. Sci., 2017, DOI: 10.1016/j.jes.2017.11.003.

6 Y. Shao, P. Zhao, Q. Yue, Y. Wu, B. Gao and W. Kong, Ecotoxicol. Environ. Saf., 2018, 158, 100-107.

7 L. Zhou, R. Li, G. Zhang, D. Wang, D. Cai and Z. Wu, Chem. Eng. J., 2018, 339, 85-96.

8 D.-l. Kong, G.-p. Lu, M.-s. Wu, Z.-f. Shi and Q. Lin, ACS Sustainable Chem. Eng., 2017, 5, 3465-3470.

9 W. Shi and X. Song, Advances in Energy and Environmental Materials, 2018, pp. 885-895, DOI: 10.1007/978-981-130158-2_89.

10 C.-M. Liu, Z.-H. Diao, W.-Y. Huo, L.-J. Kong and J.-J. Du, Environ. Pollut., 2018, 239, 698-705.

11 Y. Sun, C. Lei, E. Khan, S. Chen, D. Tsang, Y. Ok, D. Lin, Y. Feng and X. Li, Sci. Total Environ., 2018, 615, 498-507.

12 D. W. Cho, G. Kwon, Y. S. Ok, E. E. Kwon and H. Song, ACS Appl. Mater. Interfaces, 2017, 9, 13142-13150.

13 C. Yu, M. Wang, X. Dong, Z. Shi, X. Zhang and Q. Lin, RSC Adv., 2017, 7, 53135-53144.

14 Y. Guo, W. Tang, J. Wu, Z. Huang and J. Dai, J. Environ. Sci., 2014, 26, 2123-2130.

15 L. Yan, S. Li, H. Yu, R. Shan, B. Du and T. Liu, Powder Technol., 2016, 301, 632-640.

16 T. F. Marinca, H. F. Chicinaş, B. V. Neamţu, O. Isnard and I. Chicinaș, J. Alloys Compd., 2015, 652, 313-321.

17 Y. Yin, M. Zeng, J. Liu, W. Tang, H. Dong, R. Xia and R. Yu, Sci. Rep., 2016, 6, 25075.

18 S. Zhang, L. Tao, M. Jiang, G. Gou and Z. Zhou, Mater. Lett., 2015, 157, 281-284.

19 Y. Tang, H. Zhang, J. Li, G. Hou, H. Cao, L. Wu, G. Zheng and Q. Wu, J. Alloys Compd., 2017, 719, 203-209.
20 C. Yu, J. Geng, Y. Zhuang, J. Zhao, L. Chu, X. Luo, Y. Zhao and Y. Guo, Carbohydr. Polym., 2016, 152, 327-336.

21 Z. Wang, Y. Cheng, K. Zhang, C. Hao, L. Wang, W. Li and B. Hu, Fuel, 2018, 232, 495-505.

22 L. I. U. Hong-Bo, L. I. Jin and Z. Lei, J. Inorg. Mater., 2017, 32, 1159.

23 M. Li, Q. Liu, L. Guo, Y. Zhang, Z. Lou, Y. Wang and G. Qian, Bioresour. Technol., 2013, 141, 83-88.

24 N. Jiang, Y. Xu, Y. Dai, W. Luo and L. Dai, J. Hazard. Mater., 2012, 215-216, 17-24.

25 P. Regmi, J. L. Garcia Moscoso, S. Kumar, X. Cao, J. Mao and G. Schafran, J. Environ. Manage., 2012, 109, 61-69.

26 H. Tavakoli, H. Sepehrian and R. Cheraghali, J. Taiwan Inst. Chem. Eng., 2013, 44, 343-348.

27 M. Zhang, B. Gao, S. Varnoosfaderani, A. Hebard, Y. Yao and M. Inyang, Bioresour. Technol., 2013, 130, 457-462.

28 Y. Li, Q. Du, T. Liu, J. Sun, Y. Wang, S. Wu, Z. Wang, Y. Xia and L. Xia, Carbohydr. Polym., 2013, 95, 501-507.

29 L. Liu, Y. Wan, Y. Xie, R. Zhai, B. Zhang and J. Liu, Chem. Eng. J., 2012, 187, 210-216.

30 B. Wang, C. Li and H. Liang, Bioresour. Technol., 2013, 146, 803-806.

31 M. O. Ojemaye, O. O. Okoh and A. I. Okoh, Sep. Purif. Technol., 2017, 183, 204-215.

32 N. Rouahna, D. Barkat, A. Ouakouak and E. Srasra, J. Environ. Chem. Eng., 2018, DOI: 10.1016/j.jece.2018.01.036.

33 Q. Zhang, S. Dan and K. Du, Ind. Eng. Chem. Res., 2017, 56, 8705-8712.

34 A. L. P. Xavier, O. F. H. Adarme, L. M. Furtado, G. M. D. Ferreira, L. H. M. da Silva, L. F. Gil and L. V. A. Gurgel, J. Colloid Interface Sci., 2018, 516, 431-445.

35 S. J. Mousavi, M. Parvini and M. Ghorbani, J. Taiwan Inst. Chem. Eng., 2018, 84, 123-141.

36 H. J. Kim, S. Im, J. C. Kim, W. G. Hong, K. Shin, H. Y. Jeong and Y. J. Hong, ACS Sustainable Chem. Eng., 2017, 5, 66546664 .

37 S. Zhu, S.-H. Ho, X. Huang, D. Wang, F. Yang, L. Wang, C. Wang, X. Cao and F. Ma, ACS Sustainable Chem. Eng., 2017, 5, 9673-9682.

38 D. Kong, N. Wang, N. Qiao, Q. Wang, Z. Wang, Z. Zhou and Z. Ren, ACS Sustainable Chem. Eng., 2017, 5, 7401-7409.

39 C. Liu, Y. H. Chang, J. Chen and S. P. Feng, ACS Appl. Mater. Interfaces, 2017, 9, 39027-39033.

40 X. Liu, W. Si, J. Zhang, X. Sun, J. Deng, S. Baunack, S. Oswald, L. Liu, C. Yan and O. G. Schmidt, Sci. Rep., 2014, 4, 7452.

41 P.-R. Liu, Z.-Y. Yang, Y. Hong and Y.-L. Hou, Algal Res., 2018, 31, 173-182.

42 Z. Su, L. Tan, R. Yang, Y. Zhang, J. Tao, N. Zhang and F. Wen, Chem. Phys. Lett., 2018, 695, 153-157.

43 A. F. Hassan, A. M. Abdel-Mohsen and H. Elhadidy, Int. J. Biol. Macromol., 2014, 68, 125-130.

44 Q. Fang, B. Chen, Y. Lin and Y. Guan, Environ. Sci. Technol., 2014, 48, 279-288.

45 B. Zhou, Z. Wang, D. Shen, F. Shen, C. Wu and R. Xiao, Ecol. Eng., 2017, 98, 189-195.

46 X. Wei, Q. Liu, H. Zhang, J. Liu, R. Chen, R. Li, Z. Li, P. Liu and J. Wang, J. Colloid Interface Sci., 2018, 511, 1-11. 
47 G. R. Mahdavinia, S. Mousanezhad, H. Hosseinzadeh, F. Darvishi and M. Sabzi, Carbohydr. Polym., 2016, 147, 379-391.

48 Y. T. Zhou, C. Branford-White, H. L. Nie and L. M. Zhu, Colloids Surf., B, 2009, 74, 244-252.

49 L. Kuang, Y. Liu, D. Fu and Y. Zhao, J. Colloid Interface Sci., 2017, 490, 259-269.
50 Q. Zhao, Y. Huang and X. Hu, Electrochem. Commun., 2016, 70, 8-12.

$51 \mathrm{~J} . \quad$ M. Lázaro Martínez, E. Rodríguez-Castellón, R. M. T. Sánchez, L. R. Denaday, G. Y. Buldain and V. Campo Dall' Orto, J. Mol. Catal. A: Chem., 2011, 339, 4351.

52 C. Bertagnolli, A. Uhart, J. C. Dupin, M. G. da Silva, E. Guibal and J. Desbrieres, Bioresour. Technol., 2014, 164, 264-269. 